\title{
A.10 Asha Archives, Kathmandu, Ms. No. 2566
}

An incomplete Nepalese paper manuscript of 261 surviving folios seemingly from the $19^{\text {th }} \mathrm{c}^{20}$ There are two additional folios paginated as 1 and 2 with a numbered list of 122 dhāranīs. ${ }^{21}$

folios 1-4 missing

1. Saptaśatikā-prajñāpāramitā 52v [163]

2. Aparimitāyur-nāma-dhāraṇī 63r [47]

3. Yakșāșțaka-samyaksambuddhabhāșita 64r [60]

4. Jambhalajalendrasya-nāma-dhāraṇi 64v [61]

5. Vasudhārā-nāma-dhāraṇī $84 r$ [62]

6. Amoghapāśa-nāma-hṛdaya-mahāyānasūtra 94r [63]

7. Siṃhanādalokeśvarasya vyādhipraśamanī-nāma-dhāraṇī 94v [64]

8. Avalokiteśvarasya mukhodgīrṇā-siddhinikā-dhāraṇī 95r [65]

9. Sahasrabhujalokeśvarasya-nāma-dhāraṇi 96v [66]

10. Avalokiteśvarasya-nāma-dhāraṇi 97r [67]

11. Sahasrāvartā-dhāraṇī 97v [68]

12. S Ṣaḍakṣarī-mahāvidyā-nāma-dhāraṇī 99r [69]

13. Bhadracari-mahāpraṇidhānarāja 103v [70]

14. Mokṣapada-nāma-dhāraṇī 104r [71]

15. Abhayaṃkarī-nāma-dhāraṇī 104v [72]

16. Mānibhadra-nāma-dhāraṇī 105v [73]

17. Vajrapāṇi-mahārakṣā-dhāraṇī 106r [49]

18. Herukasya sarvarogapraśamanī-nāma-dhāraṇī 106v [144]

19. Vairocanī-nāma-dhāraṇī 106v [3]

20. Akṣobhya-nāma-dhāraṇī 106v [4]

21. Ratnasambhava-nāma-dhāraṇī 106v [5]

22. Amitābha-nāma-dhāraṇī 107r [6]

23. Amoghasiddhi-nāma-dhāraṇi 107r [7]

24. Durgatipariśodhanī-nāma-dhāraṇī 107v $[45,74]$

25. Cundābhagavatī-dhāraṇī 107v [75]

26. Hutāśanatejo-nāma-dhāraṇī 107v [37]

27. Bhaiṣajya-nāma-dhāraṇī 108r [38]

20 There is no colophon surviving.

21 Note that this list that looks like a table of contents only at places corresponds to the sequence of texts in the actual manuscript. The numbering of the 122 dhāranīs is inconsistent on these two folios. 
28. Mañjuśrīpratijñā-nāma-dhāraṇī 108r [58]

29. Padmahasta-nāma-dhāraṇī 108r [17]

30. Sarvamañgala-nāma-dhāraṇī 108v [39]

31. Karṇajāpā-nāma-dhāraṇī 108v [40]

32. Sarvapāpadahanī-nāma-dhāraṇī 108v [41]

33. Mahāpratisarā-rakșāvidhāna 111r

34. Suvarṇaprabhāsottamasūtrendrarāja-sarvabuddhabodhisattva-nāmadhāraṇī 111v [16]

35. Mahāpratisarā-mahāvidyā-dhāraṇī 119r [76]

36. Mahāpratisarā-kalpa-dhāraṇī 122v [77]

37. Mahāsāhasrapramardanī-nāma-vidyā-mahādhāraṇī 138v [78]

38. Mahāmāyūrī-vidyārājñī-nāma-dhāraṇi 156r [79]

39. Mahāŝìtavatī-nāma-vidyā-dhāraṇī 159r [80]

40. Mahāmantrānusāriṇī-mahāvidyā-nāma-dhāraṇī 162r [81]

41. Sarvatathāgatoṣṇisasasitātapatrā-nāmāparājitā-pratyañgirā-mahāvidyārājñī $173 v$ [83]

42. Mūlavidyā-nāma-dhāraṇī 174r [1]

43. Śatākṣara-nāma-dhāraṇī 174r [2]

44. Svalpākṣarā-bhagavatī-prajñāpāramitā 177r [164]

45. Lokātīta-stava 179r [176]

46. Jātismarā-nāma-dhāraṇī 179v [36]

47. Jātismarā-nāma-dhāraṇī 179v [36]

48. Parṇaśavarī-mahāmārīpraśamanī-nāma-dhāraṇī 180v [85]

49. Samādhirāja-nāma-dhāraṇī 181r [11]

50. Gaṇḍavyūha-nāma-dhāraṇī 181r [9]

51. Prajñāpāramitā-nāma-dhāraṇī 181r [8,56]

52. Hemāñgā-nāma-dhāraṇī 182r [86]

53. Samādhivajraguhyottaraparama-tantra-mantra-aprameyaphala 182v

54. Maitreyapratijñā-nāma-dhāraṇī 183v [87]

55. Mañjughoṣakṛti-praṇidhānarāja 184r [88]

56. Tārāpratijñā-nāma-dhāraṇī 184v [89]

57. Saddharmapuṇḍarīkāyām mantra-dhāraṇī 185v [13]

58. Dhvajāgrakeyūrā-nāma-dhāraṇī 187v [90]

59. Gāthādvaya-nāma-dhāraṇī 188v [43]

60. Șaṇmukhī-nāma-dhāraṇī 190r [44]

61. Nārāyaṇa-mahāmāyāvijayavāhinī-nāma-dhāraṇī 192v [91]

62. Lañkāvatāra-nāma-dhāraṇī 194v [12]

63. Uṣṇiṣacakravartī-nāma-dhāraṇī 194v [50]

64. Kurukullā-nāma-dhāraṇī 195r [95]

65. Jāngulī-nāma-dhāraṇī 195r 
66. Mārīcī-nāma-dhāraṇī 196r [92]

67. Vajrasarasvatī-sādhana 196v [93]

68. Vajravairocanī-stava 197r [96]

69. Śākyamunīnāṃ viśeșa-dhāraṇī 197v [35]

70. Pañcarakṣā-hṛdaya 197v

71. Sarvajñatākāra-dhāraṇīmukhapraveśa-nāma-dhāraṇī 204v [53]

72. Ușṇișacakravartī-nāma-dhāraṇī 204v [50]

73. Vasudhārāyā așțottaraśata-nāma-buddhabhāṣita 206r [97] folios 208-210 missing ${ }^{22}$

74. Uṣnịiṣavijayā-nāma-dhāraṇī 212r [100]

75. Pañcaviṃśatikā-prajñāpāramitā-nāma-dhāraṇī 214r [101]

76. Mārīcī-nāma-dhāraṇī 215v [102]

77. Grahamātṛkā-nāma-dhāraṇī 217r [103]

78. Hayagrīvakalpa-vajragandhā-nāma-dhāraṇī 217v [104]

79. Mahāmāyāvajravārāhī-nāma-dhāraṇī 220r [105]

80. Mahābhairavasya-nāma-dhāraṇī 220v [108]

81. Cintāmaṇi-dhāraṇī 221v [33,109]

82. Cintāmaṇi-dhāraṇī 222r [33,109]

83. Cundābhaț̣ārikāyā rakṣāmantra 222v [110]

84. Herukasya sarvarogapraśamanī-nāma-dhāraṇī 223r

85. Ekajațā-nāma-dhāraṇī 228r [113]

86. Grahamātṛkā-nāma-dhāraṇī 235r [103,177]

87. Daśakrodhamahābhairavāṇām-nāma-dhāraṇī 235v [114]

88. Nāmasamgīti-dhāraṇī 236r [57,115]

89. Avalokiteśvarasya mukhodgīrṇā-siddhinikā-nāma-dhāraṇī 236r [65,116]

90. Amṛtabhakṣā-nāma-dhāraṇī 236v [117]

91. Așțamahābhayaharaṇatārā-nāma-dhāraṇī 236v [118]

92. Buddhabhațāārakasya dhāraṇī 237r [119]

93. Yogāmbarasya karmarāja-nāma-dhāraṇī 237v [120]

94. Sarvalokeśvara-dhāraṇī 237v [121]

95. Khasarpaṇa-nāma-dhāraṇī 237v [122]

96. Arapacanamañjuśrī-nāma-dhāraṇī 238r [123]

97. Maitreya-nāma-dhāraṇī 238r [124]

98. Saddharmapāṭha-dhāraṇī 238v [125]

99. Vajratārā-nāma-dhāraṇī 238v [126]

100. Raktayamāri-nāma-dhāraṇī 239r [131]

101. Prasannatārā-nāma-dhārạ̣ī 239v [132]

22 Seemingly the Vajravidāraṇa and Gaṇapatihṛdaya were included here. 
102. Mahābhairavasya dhāraṇi 239v [133]

103. Siddhivighneśvarasya dhāraṇi 240r [134]

104. Mahākālasya dhāraṇī 240r [135]

105. Gạ̣eśaṣoḍaśa-nāma 240v [136]

106. Ṣaṭpāramitā-hṛdaya-nāma-dhāraṇī 241r [59]

107. Prajñāpāramitā-nāma-dhāraṇī 241v [8,56]

108. Vasudhārā-dhāraṇy-upadeśa 242r [137]

109. Mahāsaṃvarasya karmarājaviśuddhi-nāma-dhāraṇī 243v [173]

110. Hevajra-nāma-dhāraṇī 244v [174]

111. Mañjuśrībhaț̣ārakapratijñā-nāma-dhāraṇī 245r [58]

112. Punyavivardhana-nāma-dhāraṇī 245v [138]

113. Șaḍakṣarī-dhāraṇī 247r [139]

114. Sarvajñajinaratnadhātukaraṇḍaka-nāma bhagavate āryāvalokiteśvarasya stotra 250r [140]

115. Vajragāndhārī-nāma-dhāraṇī 250v [141]

116. Kālacakre nibaddha-dhāraṇī 251v [142]

117. Hevajradhāraṇapūjā-vidhi-saṃgraha 253r [143] folios 254-263 missing ${ }^{23}$

118. Hastapūjā-dhāraṇī 264v [152]

119. Nairātmya-sādhana-dhāraṇī 265r [153]

120. Vajrahūṃkārabhairavasya dhāraṇī 265r [154]

121. Hayagrīva-dhāraṇī 265v [155]

122. Hayagrīvabhairavasya dhāraṇī 266v [156]

123. Bhūtaḍāmarasaṃkṣipta-dhāraṇī 268r [157]

124. Gaganātmajaśuklavarṇavajravārāhī-nāma-dhāraṇī 269r [158]

125. Vajrayoginī-dhāraṇī 270r [159]

126. Vajraśrnnkhalā-nāma-dhāraṇī 270v [160]

127. Saṃkṣipta-dvibhujaherukasya-nāma-dhāraṇī 271v [161]

128. Pītavarṇa-prajñāpāramitā-nāma-dhāraṇī 272r [162]

129. Vasudhārā-dhāraṇī 273r [165]

130. Sitātapatrāparājitā-nāma-dhāraṇī 273v [166]

131. Vajracarcikā-nāma-dhāraṇī 273v [167]

132. Dhvajāgrakeyūrā-sādhana-dhāraṇī 275r [168]

133. Uṣnịiṣavijayā-sādhana-dhāraṇī 276v [169]

23 Possible texts here based on sequences in other collections: Mahāsarasvatī-nāma-dhāraṇi [94], Mahāpratisarā-dhāraṇi [145], Mahāpratisarā-sādhana [146], Mahāmāyūrī-nāma-dhāraṇī [147], Sāhasrapramardanī-sādhana [148], Mahāmantrānusāriṇī-sādhana [149], Pañcarakșā-sādhana-nāma-dhāraṇī [151], Pañcarakṣā-vidhāna-dhāraṇī. 
134. Mahāmāyā-nāma-dhāraṇī 277v [170]

135. Vajrajvālānalārka-nāma-dhāraṇi 278r [171]

136. Mañjuśrīpratijñā-nāma-dhāraṇī 278v [58]

the rest of the folios are missing 